\title{
Insights on Ethiopia's State of Emergency against Covid 19: A Descriptive Overview
}

\section{Shona $\mathrm{E}^{*}$}

Assistant Professor of Law, School of Law, Hawassa University, Ethiopia

*Corresponding author: Edilu Shona, Assistant Professor of Law, School of Law, Hawassa University, Ethiopia, Email: edilu2005@gmail.com

\section{Review Article \\ Volume 4 Issue 1}

Received Date: January 16, 2021

Published Date: February 08, 2021

DOI: $10.23880 /$ abca-16000157

\section{Abstract}

Ethiopia confirmed its first Covid-19 case on March 13, 2020. At the moment of writing, (11 August 2020), over 24, 000 cases of Covid-19 are confirmed and the pandemic is rising in unprecedented rate. Ethiopia has started taking various legal and informal measures prior to its first confirmation announcement on March 13, 2020 and since then. Among others, Ethiopia set up the Ministerial Committee led by the PM on February 29 and the committee gave a press release on March 16 announcing a postponement of 'large gatherings and meetings including sporting event, limiting religious institutions and places of worship to limit gatherings and closure of all public and private schools except higher learning (HI) and later on the HI was also totally closed to combat the crisis. The committee announced that security sector to enforce measures of ceasing large gatherings to maintain social distancing' on 23 March. Similar measures were also taken by Amhara, Southern and Oromia regional states among the nine member states of Ethiopian federation though without legal gazette publication. On the top of that State of Tigray declared a State of Emergency (SoE) on March, 25, 2020. In similar vein, the federal government declared SoE by the Council of Minsters (CoM) on April 8, followed by the approval of the House of Peoples Representative (HPR) on April 13, 2020. Subsequently the Council of Ministers also adopted its implementation regulation. But the implications of these measures on human rights and freedoms, social, economic and political rights of the public was not strictly thought and studied.

Thus, the main objective of this piece was to investigate implications of the above measures on human rights and rule of law principles. Accordingly, it shade some lights on substantive and procedural content of SoE in light of legality principle, proportionality and transparency, competence of government's power at different level to mention the least in contrast to measures taken in various jurisdictions.

Keywords: State of Emergency; Covid 19; Ethiopia; Human Rights; Restrictive Measures

Abbreviations: NEBE: National Electoral Board of Ethiopia; HPR: House of Peoples Representatives CoMs: Council of Ministers; MoH: Ministry of Health.

\section{Introduction}

Ethiopia confirmed its first Covid-19 case on March 13, 2020. At the moment of writing, (11 August 2020) ${ }^{1}$, over

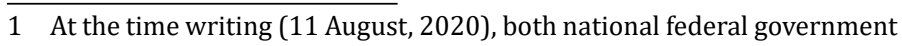

24, 000 cases of Covid-19 are confirmed and the pandemic is rising in unprecedented rate. Ethiopia took various legal and informal measures prior to its first confirmation announcement on March 13, 2020. The country set up the Ministerial Committee led by the Prime Minister on February 29 and the committee gave a press release on March 16 announcing a postponement of large gatherings

and member state level SoE are in place and the restrictions imposed have not been uplifted. 
and meetings including: sporting events; limiting religious institutions and places of worship gatherings; and closure of schools. However, the legality and constitutionality of such measures were questioned by some commentators. Before the first confirmed case of the pandemic, the election for both national and states councils was slotted to take place on August 29, 2020. However, the spread of the virus has resulted in not only postponement of the $6^{\text {th }}$ national and states elections, but also the postponement of the $4^{\text {th }}$ national housing and population census until the $\mathrm{MoH}$ confirms the virus has gone. The verdict of the HoF, largely composed of the ruling party, becomes the center of political and legal debates in the history of the federation.

Be that as it may, it is important to look at the chorological order of regulatory measures against Covid 19 in Ethiopia. To begin with Ethiopia set up the Ministerial Committee led by the Prime Minister Abiy Ahmed on February 29, 2020. The Ministerial Committee announced a postponement of large gatherings, meetings, sporting events, worshiping; and closure of all schools on March 16. Such measure was followed by the Ministry of Health announced the country decided to quarantine all passengers arriving in Ethiopia for 14 days on March 20.

Regarding legal measures at the state level, the state of Tigray declared a statewide State of Emergency March 25, 2020. Multi-Sectorial Preparedness and Response Plan was launched by the ministry of Health on April 03. One of the significant steps in this process was a declaration of state of emergency by the Council of Ministers (CoMs) on April 8 and House of Peoples Representatives (HPR) approved the SoE of the CoMs by Proclamation No $1189 / 2020$ on the $11^{\text {th }}$ of April. In similar vein, the CoMs issued a regulation of detailing measures to be taken on the same date. On April 12, the Ministry of Health published the National Comprehensive Covid-19 Management Handbook.

At this juncture it is important to mention that House of Peoples Representative (HPR) approved the postponement of pre-elections preparation of the National Electoral Board of Ethiopia (NEBE). April 30, 2020. On the $5^{\text {th }}$ of May, the HPR endorsed constitutional interpretation of the Constitutional provisions pertaining to the extension of election during the state of emergency. It is also important to note what other progress taken by the Ministry of Health (MoH) reported community transmission rate with $67 \%$ of cases testing positive for Covid-19 on the $29^{\text {th }}$ of May.

Other important measure to be noted in the fighting process of the pandemic in Ethiopia was the action of the House of Federation (HoF) on $11^{\text {th }}$ of June. The House rendered unprecedented decision that declared the postponement of the $6^{\text {th }}$ National and Regional Elections due to the challenges caused by Covid-19. Additionally, the Ministerial Committee revised the quarantine period for persons entering the country from 14 to 7 days on June 19 . Furthermore, on the $11^{\text {th }}$ of July 11 the House of Federation approved the postponement of the $4^{\text {th }}$ national housing and population census due to Covid-19 pandemic. Similarly, the PM called for increasing testing to reach 200,000 people and cover millions of population through people community based activities campaign against Covid 19 on August 1, 2020.

\section{Constitutional basis and Procedures of SoE on Covid 19}

The federal government's authority to control pandemic diseases emanates from the Federal Democratic Republic Constitutional provisions of Articles 51(3) \& 93(1a). The states' powers in the area of controlling a pandemic can also be linked with their concurrent power on public health since the SoE is declared for controlling the spread of endemic diseases in terms Article 93(1b) of the Constitution. The power of declaring SoE in response to the nationwide and statewide public health crisis is concurrently shared between the CoMs of federal government and State Councils respectively. The CoMs declared SoE as per the Article 93(1a,b) of the Constitution on April 8, 2020 and the HPR approved it on April 11, 2020(Proclamation No. 1189/2020). The state of Tigray also declared a statewide SoE on March, 25, 2020. Until such adoption, "previous emergency measures were implemented in other parts of the country expect state of Tigray" (EHRC, 2020). The effect of such laws limits almost majority of fundamental human rights and democratic rights save to non-derogable rights explicitly provided in the Constitution (Article 93, sub 4c). Additionally the process of adoption was also contested for absence of adequate deliberation on the content of the rights and duties to be imposed against citizens.

Indicating the significance of measures and identifying justifications that really activated the 'state of emergency during the crisis is very important point that any reasonable citizen could pose. At this juncture, one may also ask what kinds of controls are established in order to limit the extraordinary powers attributed to the executive branch of government under Ethiopian jurisdiction.

The rationale for declaring nationwide SoE was that the 'Covid-19 cannot be controlled through regular law enforcement methods' (Preamble of Proclamation 3/2020). Additionally, the preamble specifically stated that the adverse political, social and economic impacts of the pandemic and the need to mitigate humanitarian crises of the pandemic could be avoided only through the 'coordinated' decision making and implementation processes. The CoMs is 
authorized to delineate rights and freedoms it would suspend for the purpose of containing the pandemic (Article 4, SoE Proclamation No 3/2020). The Constitution also envisages that a SoE is subject to the approval of the HPR and shall be assessed through the SoE Inquiry Board (Article 94(2,5) FDRE Constitution,). The roles of state of Inquiry Board include, publicizing the names of individuals arrested on account of the SoE together with the reasons for their arrest; inspecting and follow up measure taken is inhumane; recommending to the Prime Minister or to the CoMs corrective measure in case of inhumane treatment; ensuring the prosecution of perpetrators of inhumane acts and submitting its views to the HoP on a request to extend the duration of the SoE (Article, 93(6 a-e) FDRE Constitution). The HPR has established the Inquiry Board and appointed seven members of the Board (Article 3, Proclamation No. 1189/2020). However, the role of the parliamentary control of the content of restriction prior to its adoption was doubtful. The HPR did not imply any indication, framework, or guidelines on the kind of rights and freedoms that the latter can justifiably suspend and the extent of the suspension.

\section{Vertical and Horizontal Competence on Declaring SoE on COVID 19}

Ethiopia is a federal state and the Constitution demarcates the powers and functions of the federal government on the one hand and members of the federation on the other hand. At the moment, both federal government and the state of Tigray $^{2}$, declared SoEs to combat the crisis.

The CoMs adopted the implementation regulation which incorporated the detailed measures and restrictions related to the Covid-19. The SoE is not only applicable nationwide but also it incorporated the overriding clause indicating that no state level law that is contradictory to it would be effective. The issue here is what would be the status of measures taken in terms of the member states SoE competences which go against the overriding clause of the federal SoE and how could it be resolved within the principle of federalism Degu T, et al. [1]; Ayele ZA, et al. [2]. At this juncture, one may propose the issue would be determined by the HoF through constitutional interpretation if such contradiction between federal and state legislation arose. But in the current case, there have been no legal cases brought to the HoF regarding the two State of Emergency laws. Additionally, from the stand point of combating the crisis, a coordinated national response was called for in response to an unprecedented crisis like this global pandemic rather than conflicting application of measures among the member states. Moreover, the SoE incorporated provisions that may open a door of

2 The state of Tigray declared the SoE for three months and extended its application for more three months until the last week of September, 2020 'centralization of information dissemination with respect to the Covid-19 dangerously threatens freedom of expression' (EHRC, 2020). The situation of providing information about Covid-19 is restricted at the center unless the permission from the Ministerial Committee granted and this may result in delay of relevant facts about the crisis.

It is argued that any constitutions are expected to impose specific limits and checks to the exercise of emergency powers by the executive and parliament needs to be in session and regularly meet throughout the emergency in order to properly discharge its oversight function Elliot B, et al. However, the SoE went against this expectation by prohibiting all types of meetings including government meetings without making any exception even for its regular meetings (Article 3(1), SoE Regulation No. 466/2020 1).Thus the Parliament and its Inquiry Board have been convening to evaluate the measures taken by the executive after securing the permission for the meeting from the Ministerial Committee (Article 3(2)).

It is stated that the SoE will remain in force for five months since 8 April 2020. Although there is no clear indication on the possibility of extension, the Federal Democratic Republic of Ethiopia Constitution envisages the possibility of extension if the HPR renewed the SoE after the end of four months (Article 93 (3), FDRE Constitution). But in practice the government did not extend the restriction as per the constitution and the SoE was expired without any adequate legal backups at the time of writing this piece.

\section{The Implication of SoE on Human Rights and Freedoms}

There is no doubt that what powers does the state of emergency grant to the executive branch of federal government of Ethiopia. It is was understood that the subsequent adoption of the CoMs' regulation detailed the suspension of rights and measures to be taken to counter and mitigate the humanitarian, social, economic and political damage that could be caused by Covid $-19^{3}$. The justification for granting such powers to the executive branch, according to the Attorney General, was to enable the executive the suspension of rights in a flexible manner in view of everchanging objective circumstances rather than fixed set of restrictions makes it possible to manage the imposition of emergency measures. ${ }^{4}$ Some prohibited activities include and duties imposed include banning the gatherings of more than four people prohibit; and requires buses, trains and

\footnotetext{
3 State of Emergency Proclamation No. 3/2020 Implementation Regulation No.466/2020, Article 3 provided 26 prohibited activities and Article 4 provided about 17 duties and obligations

4 Short Explanatory Note on State of Emergency Proclamation No. 3/2020, Office of the Federal Attorney General, (April 2020), pp. 6-7.
} 
other vehicles to use only half their capacity to transport people. Additionally, it states closure of clubs, bars, theaters and cinemas and schools of all levels.

The SoE regulation incorporated provisions that suspension of civil lawsuits in whole or in part (Article 6 (4), Regulation 466/2020). The suspension of criminal procedure code and criminal procedural provisions in other laws would undermine procedural rights of that are guaranteed under the Constitution and international human rights treaties to which Ethiopia is a party. Some provisions imposed onerous burdens on the right to property and business freedoms of business owners. Furthermore, the imposition of mandatory reporting obligation on general public if they suspect individuals of being infected with Covid-19 disregarded the right to privacy and confidentiality of Covid-19 patients (Article 4, Regulation No. 466/2020). Additionally, it is not clear what is meant by persons "suspected of being infected with virus".

On top of that the SoE under discussion was criticized for being an overly criminal and potentially discriminatory approach to the Covid-19 pandemic which violates the right to privacy and confidentiality of Covid-19 patients and vulnerable groups; broadly crafted expropriation power on private property; some provisions appeared to having a chilling effect on freedom of expression" (EHRC Report, 2020) and there are also provisions that place disproportionate burdens on business freedoms. Ayele ZA, et al. [3] has argued that imposition of the same penalty of simple imprisonment up to 3 years or a fine up to 200,000 Ethiopian Birr for a wide range of different crimes seems against the principle of legality.

\section{The Role of Judiciary and Expertise Evidences}

It is true that the judiciary questions the legitimacy of government decisions as its inherent power of check and balance in general in the case of restrictive measures in particular. The experiences of various jurisdictions indicated that there are significant decisions from the judiciary branch of governments.

The constitutionality of legislation including the SoE and governmental organs is to be decided by the $\mathrm{HoF}^{5}$. The term of the current parliament and state councils, which have a five year term and elections have to be held at least a month before the expiry of the term will come to an end on 10 October 2020 (Cumulative reading of Article 58(3)

\footnotetext{
5 The powers and functions of the Council are provided in Article 84 of the Constitution and Article 6 of Proclamation No. 250/2001. In making its decision, the HoF relies on the professional advice or recommendation made by the Council of Constitutional Inquiry, which is established by the Constitution.
}

and Article 54 of the FDRE Constitution). On the other hand, the SoE of the CoMs resulted in suspension of all political activities for five months including the election which was slotted to be conducted on 29 August 2020. The problem lies in that the Constitution does not provide any guidelines on how the country would be governed when such an emergency prevents the holding of the general elections.

But the HPR requested an advisory opinion from the Council of Constitutional Inquiry (CCI) and HoF on what would be the fate of the current Parliament and government and how and by whom the country would be governed after October Ayele ZA, et al. [4] Upon such request, the CCI/ HoF opted constitutional interpretation under the situation of SoE among the four opinions suggested by the house. Accordingly the HoF decided that the sixth general elections to be postponed. However, prominent experts questioned the legality of such decision by stating that that the HoF has impliedly left the current government to decide if and when to hold the sixth national elections and in effect allowed it to continue governing the country for an ambivalent period of time. This decision was expressed in the words of legal experts 'self-dealing' or 'self-serving' and the verdict was right "because I said so" respectively Ayele ZA, et al [5]; Geremew ST, et al. [6].

\section{The Role of Experts/Scientific Evidences}

In the process of declaring state of emergency, it is important to raise a question of what role has been parleyed of expertise (medical expertise) and political authority so that on could understand to what extent the government officials referred to scientific/expert theories and evidence.

Regarding such query, it is known that there was 'no dedicated consultations beyond public authorities and health experts, including Africa CDC, have been conducted owing to the emergency situation and the need to address issues related to Covid-19 March 11, 2020(The Ethiopia Covid-19 Sep, 2020). However, "more than 700 teams of health experts were deployed across the country to conduct contact tracing, besides a door-to-door screening and surveillance campaign by end of April" Fana BC, et al.

The government set the Ministerial Committee, the office of the Prime Minister and the Ministry of Health as its focal point information and progressive measures (Article, 3(16) Regulation 466/2020,)). Subsequent source of daily status update is available in the Ethiopian Public Health Institute (EPHI) YouTube Channel (EPHI, 2020). Additionally, a Ministerial Committee, chaired by the Deputy Prime Minister and accountable to the PM, was established. The sub committees were focused on: multidimensional containment actions, resource mobilization, market stabilization and 
other measures to control the spread of the pandemic in the country (The Ethiopian Herald, 2020). The powers and responsibilities of the committee include: overseeing, coordinating, compiling and analyzing the necessary data; establishing various sub-committees at federal, regional, municipal and woreda (equivalent to district in other jurisdiction) level; and proposing additional restrictions as it deems necessary (Article, 5(16), Regulation 466/2020).

At this juncture, many inquired what tasks have been attributed to them (e.g. a prior evaluation of the declaring state of emergency or whether there existed study of specific type or guidelines used by the government as a basis for political choices. Similarly, when and at which conditions the limitations imposed by the state of emergency have been modified or cancelled, considering the development of the health crisis and whether there was a monitoring system collecting the epidemiologic data, used by public authorities in order to evaluate the necessity of a return to more restrictive measures.

Regarding such concerns this writer have observed that the Ministry of Health under taken a door to door survey of identifying individuals contracted with the Covid 19 and reported that it reached out over 3.6 million households in April. Furthermore, the Ministerial Committee has been evaluated the outcome of measures taken to combat the pandemic at least monthly from April to August 1. The Committee modified some decisions and passed a mandatory requirement for those who come from abroad to produce a certificate of negative test for Covid-19 (tested in 72 hours before arrival) so as to be put in quarantine for 7 days and additional 7 days at home with full cautions assisted by health expert (ENA, 2020) ${ }^{6}$. Similarly, the government allowed a burial to be undertaken by respective relatives of deceased while observing necessary protocols but in the absence of families the burial will be conducted by the Government. The Committee also called for increment of testing for the launch of a one-month nationwide mass testing' from August 1- Sep 6 , to reach 17 million of population for the want of trends (Press release office of the Prime Minister, 2020).

\section{Conclusion}

Since the first confirmation of Covid-19 case, Ethiopia has taken several measures including declaring nation-wide SoE and the state of Tigray declared its own statewide since both governments share the power concurrently. However, the legal measures have restricted fundamental human and democratic rights of citizens except for non-derogable

\footnotetext{
6 The decision was made for challenges given the trend of the virus as well as the fact that the maturity period of patients has now been known to be between 6- 7 days since June 19 .
}

provisions of the Constitution (Arts, 1, 18, 25, 39(1\&2)). The pandemic accompanied by the SoE result in the postponement of the $6^{\text {th }}$ national and state councils' election, postponement of national housing and census through the interpretation of the Constitution by the HoF. Accordingly the decision of the House of Federation has extended the term of the HPR and state councils until the MOH confirms the disappearance of the pandemic. Such measures induced various heated debates. The debate took attention of opposition parties and legal experts at least for two reasons. First, the HoF could not serve as impartial organ in interpreting the constitution since it is predominantly occupied by the ruling party. Additionally, it was argued that the HoF disregarded several available alternatives including call for constitutional amendment and/ or establishing a transitional government which comprises various stakeholders from opposition parties, civil societies rather extending the term of incumbent government under the disguise of constitutional interpretation.

\section{References}

1. Degu T (2020) COVID-19 state of emergency and the federal balance of power. Ethiopian Insight.

2. Ayele ZA (2020) Analysis: COVID19 and federalism in Ethiopia: on constitutional and political implications. Addis Standard.

3. Ayele ZA (2020) State of emergency: right move with shades of problematic provision. Addis Standard.

4. Ayele ZA (2020) Federalism and the COVID-19 crisis: The perspective from Ethiopia.

5. Ayele ZA (2020) Ethiopia's 'Unusual Constitutional Umpire': Revisiting the Role of the House of Federation'. 50 Shades of Federalism.

6. Geremew ST (2020) Council of Constitutional Inquiry verdict: "Because I said so". Ethiopian Insight.

7. Birru JG (2020) Constitutional Impasse in Ethiopia: Finding a Solution for the Current Postponement of the 2020 General Election in Ethiopia. Verfassungsblog.

8. Derso SA (2020) Analysis: of the legal status of Ethiopia's \# covid19 measures. Addis standard.

9. Regassa A (2020) COVID-19 triggers authoritarian relapse. Ethiopian Insight.

10. Worku B (2020) Op-ed: complacency and behavioral change in the era of the coronavirus. Addis standard.

11. Zemzem (2020) Containing the spread of COVID-19 in Ethiopia. JoGH 10(1). 


\section{Legislation}

1. No. 251/2001 Consolidation of the H0use of the Federation and the Definition of its Powers and Responsibilities Proclamation. Ethiopian Legal Brief.

2. Proc No. 1-1995 Constitution of the Federal Democratic Republic. Ethiopian Legal Brief.

3. State of Emergency Proclamation Enacted to Counter and Control the Spread of COVID-19 and mitigate its Impact Proclamation No. 3/2020. Ethiopian Legal Brief.

4. Proclamation No. $1189 / 2020$ to Approve the State of Emergency Proclamation No. 3/2020 Enacted to Counter and Control the Spread of COVID-19 and Mitigate its Impact.

5. State of Emergency Proclamation No. 3/2020 Implementation Regulation No.466/2020.

\section{Website Sources}

1. Elliot B (2018) Emergency Powers. International IDEA Constitution-Building Primer 18.

2. (2020) Managing the Politics of Ethiopia's COVID-19 Crisis. Crisis Group.

3. (2020) Ethiopia postpones August elections due to coronavirus.

4. Federal Ministry of Health (2020) National Comprehensive Covid19 Management Handbook

5. (2020) Ethiopian Public Health Institute YouTube Channel.

6. Fana BC (2020) Ministerial Committee Reviews
COVID-19 Containment Activities.

7. Al-Mariam G (2020) Ethiopia: Desperate Times Call for Extraordinary Constitutional Measures (Proclamation 3/2020) (Part I).

8. (2020) Ethiopia's state of emergency risks controversy.

9. Stakeholder Engagement Plan (SEP) Ethiopia COVID-19 Emergency Response Project.

10. (2020) Observe and report, inspecting SoE implementation. Ethiopian Press Agency.

11. (2020) Ethiopia's efforts, positive outcomes of curbing COVID-19 pandemic. Ethiopian Press Agency.

12. (2020) Press Statement on Coronavirus Disease (COVID-19). The Ethiopian Public Health Institute's (EPHI).

13. (2020) The COVID-19 National Ministerial Committee met this morning.

14. (2020) Ministerial Committee for the Defense of Covenant 19.

\section{Other Sources}

1. Ethiopian Human Rights Commission (2020). Legal/ Human Rights Analysis of the Declaration of State of Emergency in Ethiopia in the Context of the COVID-19 Pandemic.

2. (2020) Short Explanatory Note on State of Emergency Proclamation No. 3/2020. Office of the Federal Attorney General, pp: 6-7. 